\title{
Anticancer Effect of Bovine Lactoferrin on Breast Can- cer Cell Line MCF7 and the Evaluation of Bax and Bak Genes Expression Involved in Apoptosis
}

\author{
Amir Khalafi ${ }^{1}$ (D) Fatemeh Moradian $^{1 *}$ (D), Alireza Rafiei ${ }^{2}$ (D) \\ 1. Department of Basic Sciences, Sari Agricultural Sciences and Natural Resources University, Sari, Iran. \\ 2. Molecular and Cell Biology Research Center, Faculty of Medicine, Mazandaran University of Medical Sciences, Sari, Iran.
}

\begin{tabular}{|c|c|}
\hline $\begin{array}{l}\text { Use your device to scan } \\
\text { and read the article online }\end{array}$ & Chat on Khalafi A Moradian F. Rafiei AR. Anticancer Effect of Bovine Lactoferrin on Br \\
\hline 口. & $\begin{array}{l}\text { the Evaluation of Bax and Bak Genes Expression Involved in Apoptosis. Research in Molecular Medicine. 2020; 8(3):107-116. } \\
\text { https://doi.org/10.32598/rmm.8.3.726.3 }\end{array}$ \\
\hline Gring & 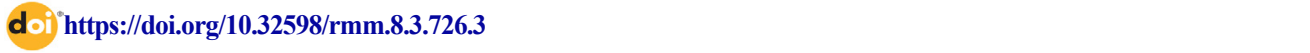 \\
\hline
\end{tabular}

\section{(i) (8)}

Article Type:

Research Article

\section{Article info:}

Received: 2 May 2020

Revised: 10 Jun 2020

Accepted: 29 Jun 2020

Keywords:

Anticancer, Breast cancer, Bak gene, Bax gene, Lactoferrin

\begin{abstract}
A B S T RA C T
Background: Lactoferrin is a glycoprotein with antimicrobial, antioxidant, immune-modulating, antiviral, and most importantly anticancer properties. In the present study, the effect of lactoferrin on breast cancer cell growth and the expression of Bax and Bak genes are evaluated.

Materials and Methods: MCF7 cells were cultured in a 96-well plate with $1 \times 105$ cells in each well. Different lactoferrin concentrations of $0,50,300,600$, and $800 \mu \mathrm{g} / \mathrm{mL}$ were added to each well in three replicates and the well was incubated for 24 hours. After treatment, cell survival was measured using the MTT assay. To determine the level of expression of Bax and Bak genes, the cells were treated with lactoferrin concentrations of 0,50 , and $800 \mu \mathrm{g} / \mathrm{mL}$ in 2 replicates for 24 hours. Then RNA extraction was performed and cDNA was synthesized immediately and the expression of the genes in the presence of beta-actin reference gene and cyber-green fluorescence color was investigated with real-time reactions.

Results: The cells viability in lactoferrin concentrations of $0,50,300,500$ and $800 \mu \mathrm{g} / \mu \mathrm{L}$ were $100 \%$, $94 \%, 83 \%, 62 \%$, and $32 \%$, respectively. The expression level of the Bax gene at a concentration of 50 $\mu \mathrm{g}$ increased by 2.71 times and in $800 \mu \mathrm{g}$ concentration decreased by 0.88 times. Also, the expression level of the Bak gene at concentrations of 50 and $800 \mu \mathrm{g}$ increased by 1.23 and 1.0 fold, respectively. Statistical analysis of the data indicated that the expression levels of two genes at a concentration of $50 \mu \mathrm{g} / \mathrm{mL}$ of lactoferrin significantly increased $(\mathrm{P}<0.01)$, compared to the control. The significance level in this study was set at $\mathrm{P}<0.05$.

Conclusion: In this study, lactoferrin showed a growth inhibitory effect on breast cancer cells and increased the expression of Bax and Bak genes involved in apoptosis at a concentration of $50 \mu \mathrm{g} / \mathrm{mL}$.
\end{abstract}

\footnotetext{
* Corresponding Author:

Fatemeh Moradian, PhD.

Address: Department of Basic Sciences, Sari Agricultural Sciences and Natural Resources University, Sari, Iran.

Phone: +98 (11) 33687655

E-mail:f.moradian@sanru.ac.ir;f.moradian@umz.ac.ir
} 


\section{Introduction}

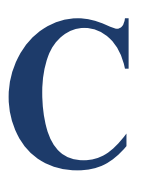

ancer refers to the uncontrolled growth and abnormal development of cells in the body. The most common cause of death due to cancer in women is breast cancer [1]. Despite advances in cancer treatment, there is a sense of the need for anti-cancer agents that increase cellular resistance.

Lactoferrin is a multi-function protein that performs several biological functions and has antibacterial, antiviral, antifungal, anti-inflammatory, anti-tumor, antioxidant, and immunological activities [2]. Antitumor activity of lactoferrin in cancer cells has been shown in various tissues, such as pharynx, lung, bladder, liver, colon, stomach, and breast [3-6]. It has also been reported that lactoferrin induces apoptosis in the cancers of the colon, lung, stomach, esophagus, and breast [7-10].

Lactoferrin can induce apoptosis through intracellular and extracellular pathways in cancer cells [11]. The extracellular mechanism is related to its interaction with cell membrane receptors [12]. And the intracellular mechanism is associated with cell apoptosis and cell cycle arrest [13]. The mechanism of lactoferrin cytotoxic actions like membrane disruption, apoptosis, and cell cycle arrest have been reported in different cancer cells [14-16].

One of the important functions of lactoferrin is the regulation and strengthening of the immune system. The immune system cannot destroy cancer cells since tumor cells have a suppressive effect on the immune system. Lactoferrin can activate the immune system in two ways; on the one hand, it supports the proliferation, differentiation, and activation of the immune system cells and thus boosting the immune system and on the other hand, it inhibits the inflammatory factors [17]. Lactoferrin increases the amount of anti-inflammatory interleukin-10 and cytokine-mediated stimulation of natural killer (NK) cells that play an important part in the defense against tumor growth while cancer cells inhibit them [17, 18]. Lactoferrin affects NK cells activation that leads to cancer cell lysis [11].

Bax and Bak genes are pro-apoptotic members of the Bcl-2 family needed to program cell death. Dimerization of Bax and Bak are crucial for the activation of mitochondria resulting in a change in the mitochondrial membrane potential, production of reactive oxygen species, and release of cytochrome $\mathrm{C}$, which activates a downstream caspase program [19-21].
The inducible expression following a death stimulus translocation of Bax into the mitochondria where it becomes an integral membrane protein and is crosslinked as a dimer. Bak is in the outer membrane of the mitochondria that inhibitors of apoptosis prevent it from oligomerization. When this inhibition is removedBak like Bax forms a dimer and promotes membrane permeability $[22,23]$. According to previous studies, the upregulation of Bax and Bid via lactoferrin could induce apoptosis in stomach cancer cell line SGC-7901 [10] Lactoferrin induces apoptosis in Jurkat $\mathrm{T}$ leukemia cells and MDA-MB- 435 breast carcinoma cells by the induction of caspases 2, 3, and 9 activities [24]. Bak can induce apoptosis in various mammalian cells and a decrease in Bak protein expression was reported in primary colorectal adenocarcinomas and gastric adenocarcinomas when compared with the normal tissue $[25,26]$. Since Bak and Bax can form a heterodimer with anti-apoptotic Bcl-2 and Bcl-xL and induce apoptosis, Bak maybe a tumor suppressor in some cancers [27, 28]. Therefore, reagents that affect the expression of Bak or Bax can control cancer cell growth.

In this study, the effect of various concentrations of lactoferrin on the growth of breast cancer cell lines (MCF-7) and expression of two apoptotic genes, Bax and Bak, were investigated.

\section{Materials and Methods}

\section{Determination of lactoferrin concentration and purity}

Lactoferrin was extracted from cow milk colostrum and purified using cation exchange chromatography [7]. The purity of lactoferrin was checked with $10 \%$ SDSPAGE (sodium dodecyl sulfate-polyacrylamide gel electrophoresis). The concentration of purified protein was determined by the Bradford method.

\section{Cell culture and treatment with lactoferrin}

MCF-7 human breast cancer cell line was purchased from the Pasteur Institute (Iran). MCF-7 cells were cultured in RPMI-1640, containing 20\% FBS, and incubated at $37^{\circ} \mathrm{C}$ with $5 \% \mathrm{CO}_{2}$.

After the growth of MCF-7 cells and reaching 70\% confluency, the cells were transferred to a 96 -well plate with $5 \times 10^{3}$ cells in each well and incubated for 24 hours. Then, the different concentrations of lactoferrin $(0,50$, 300,600 , and $800 \mu \mathrm{g} / \mu \mathrm{L}$ ) were treated in three replicates. 


\section{MTT assay}

To measure the effect of lactoferrin on the growth inhibition of the cancer cells, MTT assay was performed, according to Sigma protocol, and the absorbance was measured at $490 \mathrm{~nm}$ using ELISA reader (Stat Fax 2100, Belgium). Primers were designed with Gene Runner and synthesized by Gene-Fanavaran. Nucleotide sequences used for the design of probe-primers were retrieved from the NCBI database and the designed probe-primers were aligned by BLAST to confirm gene specificity.

\section{RNA extraction}

The grown cells on the 6-well plate were treated with three different concentrations of lactoferrin containing 0 , 50 , and $800 \mu \mathrm{g} / \mathrm{mL}$ for 24 hours. Then, the total RNA was extracted using the EZ-10 spin column total RNA mini-prep kit (Takara, Japan) according to the manufacturer's manual. The quality of extracted RNA was checked up on agarose gel electrophoresis.

The complementary DNA (cDNA) was synthesized using the Revert Aid first-strand cDNA synthesis kit (Takara, Japan). The quality and quantity of cDNA were analyzed by agarose gel electrophoresis and spectrophotometer, respectively. The cDNA was stored at $-20^{\circ} \mathrm{C}$.

\section{Real-time PCR}

At first, the PCR reaction was done for the evaluation of the amplification of Bax and Bak genes using specific primers. The specific primers were designed based on the $\mathrm{BH} 3$ conserved region of the two genes and $\beta$-actin considered as a reference gene for data normalization (Table 1). The LightCycler FastStart DNA Master PLUS SYBR Green I kit (Takara, Japan) was used for a real-time PCR reaction. The reaction was prepared in final volume 25 $\mu \mathrm{L}$ contained, cDNA as template, specific primers, TB green, ROXI, and ddH2O. The thermal cycling of realtime PCR was the first denaturation at $95^{\circ} \mathrm{C}$ for $10 \mathrm{~min}$; followed by 40 cycles, including denaturation at $95^{\circ} \mathrm{C}$ for 30 seconds; annealing at $59^{\circ} \mathrm{C}$ for $30 \mathrm{~s}$; extension at $72^{\circ} \mathrm{C}$ for $45 \mathrm{~s}$, and the final extension at $72^{\circ} \mathrm{C}$ for $10 \mathrm{~min}$. The reaction was performed in the Step-One Plus ${ }^{\mathrm{TM}}$ realtime PCR (Australia).

All samples containing different concentrations of lactoferrin treatment and reference genes were amplified in triplicate. After amplification of the genes, data analysis was performed using $2^{-\Delta \Delta \mathrm{CT}}$ methods as follows: $\Delta \mathrm{CT}$ (Bak or Bax genes) $=\mathrm{Ct}$ (Bak or Bax genes $)-\mathrm{Ct}$ ( $\beta$-actin), $\Delta \Delta \mathrm{CT}=\Delta \mathrm{CT}$ (treatment cells) $-\Delta \mathrm{CT}($ control $)$, where $\mathrm{Ct}$ was the threshold cycle value for the amplified genes (Livak and Schmittgen, 2001), then the fold changes were measured as $2^{-\Delta \Delta \mathrm{CT}}$.

\section{Statistical analysis}

The average genes expression in the treated cells with lactoferrin as well as the control cells were compared using the Tukey test in One-way ANOVA using SPSS V. 21.

\section{Results}

The purity of lactoferrin was confirmed on $10 \%$ SDSPAGE gel electrophoresis and the $80 \mathrm{kDa}$ band of lactoferrin observed on the gel (Figure 1). The concentration of lactoferrin was determined as $3 \mathrm{mg} / \mathrm{mL}$.

\section{Cell viability using MTT assay}

To evaluate the cytotoxic activity of lactoferrin against human breast cancer cells (MCF-7) the cell survival was measured using MTT assay. The results showed that the viability rates of the cells in treatments with lactoferrin concentrations of $0,50,300,600$, and $800 \mu \mathrm{g} / \mathrm{mL}$ after 24 hours were $100 \%, 94 \%, 83 \%, 62 \%$, and $32 \%$, respectively (Figure 2). By increasing the concentration of lactoferrin, the viability of the cell decreases, as a result, the effect of lactoferrin is dose-dependent.

\section{cDNA synthesis and PCR reaction}

After the synthesis of cDNA, the polymerase chain reaction with specific primers was done for three genes. The bands of amplified genes were observed on the agarose gel (Figure 3).

\section{Study of gene expression by real-time PCR}

Gene expression levels were evaluated after treatment of three concentrations of 0,50 and $800 \mu \mathrm{g} / \mathrm{mL}$ of lactoferrin for $24 \mathrm{~h}$ on MCF7 cells. The genes amplification curves are visible in the following graph (Figure 4). The fold change in gene expression determined based on $\Delta \Delta \mathrm{CT}$ and the amount of $-\Delta \Delta \mathrm{CT}$ and $2^{-\Delta \Delta \mathrm{CT}}$ are presented in Tables 2 and 3.

The expression level of the Bax gene at concentrations of $50 \mu \mathrm{g}$ of lactoferrin increased by 2.71 fold and in $800 \mu \mathrm{g}$ decreased by 0.88 fold. The expression level of the Bak gene at a concentration of 50 and $800 \mu \mathrm{g}$ of lactoferrin increased by 1.23 and 1.01 fold, respectively. Statistical analysis of the data indicated that the expression levels of two genes of Bax and Bak at a concentration of $50 \mu \mathrm{g} / \mathrm{mL}$ of lactoferrin were significantly increased, compared with the control 
Table 1. Primers used for amplification of the genes

\begin{tabular}{ccc}
\hline Gene & Sequence (5'-3') & Product Size (bp) \\
\hline$\beta$-actin/F \\
$\beta$-actin/R & CCTGGGCATGGAGTCCTGT & $151 \mathrm{bp}$ \\
Bax/F & ATCTCCTTCTGCATCCTGTCG \\
Bax/R & CGAGTGTCTCAAGCGCATC & $150 \mathrm{bp}$ \\
Bak/F & GGTTCTGATCAGTTCCGGCAC \\
Bak/R & GCTCGCCATCATCGGGGAC & $127 \mathrm{bp}$ \\
\hline
\end{tabular}

Table 2. The amount of $-\Delta \Delta \mathrm{CT}$ and $2^{-\Delta \Delta C \mathrm{CT}}$ for Bak

\begin{tabular}{cccc}
\hline $\mathbf{2}^{-\Delta \Delta C T}$ & $\Delta \mathbf{\Delta C T}$ & $\boldsymbol{\Delta C T}$ & Treatment \\
\hline 1 & 0 & 6.85 & 0 \\
1.23 & -0.03 & 6.55 & 50 \\
1.01 & -0.01 & 6.86 & 800 \\
\hline \% Rm
\end{tabular}

Table 3. The amount of $-\Delta \Delta C T$ and $2^{-\Delta \Lambda C T}$ for Bax

\begin{tabular}{cccc}
\hline Treatment & $\Delta \mathbf{C T}$ & $\boldsymbol{\Delta \Delta C T}$ & $\mathbf{2}^{-\Delta \Delta C T}$ \\
\hline 0 & 7.06 & 0 & 1 \\
50 & 5.62 & -1.44 & 2.71 \\
800 & 7.25 & 0.19 & 0.88 \\
\hline
\end{tabular}

$(\mathrm{P}<0.01)$. At a concentration of $800 \mu \mathrm{g} / \mathrm{mL}$ of lactoferrin, the expression of the Bak gene increased compared with the control and was statistically significant; however, the expression of the Bax gene was significantly lower than the control gene $(\mathrm{P}<0.02)$. According to the results of Bax and

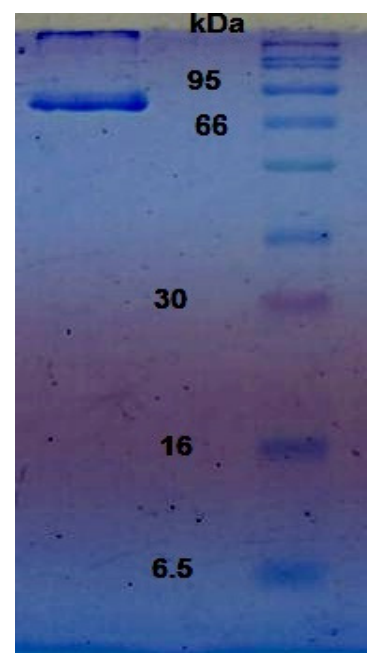

$80 \mathrm{kDa}$

Figure 1. 10\% SDS-PAGE

काIIIII

Line 1, BLUltra Prestained Protein Ladder (GeneDrex); line 2, $80 \mathrm{kDa}$ band of purified lactoferrin
$B a k$ genes expression at the concentration of $50 \mu \mathrm{g} / \mathrm{mL}$ of lactoferrin, expression increased, which is likely to be more effective in expressing these genes in this type of cancer (Figure 5). For each sample, measurements were done at least in triplicates; error bars represent standard deviations.

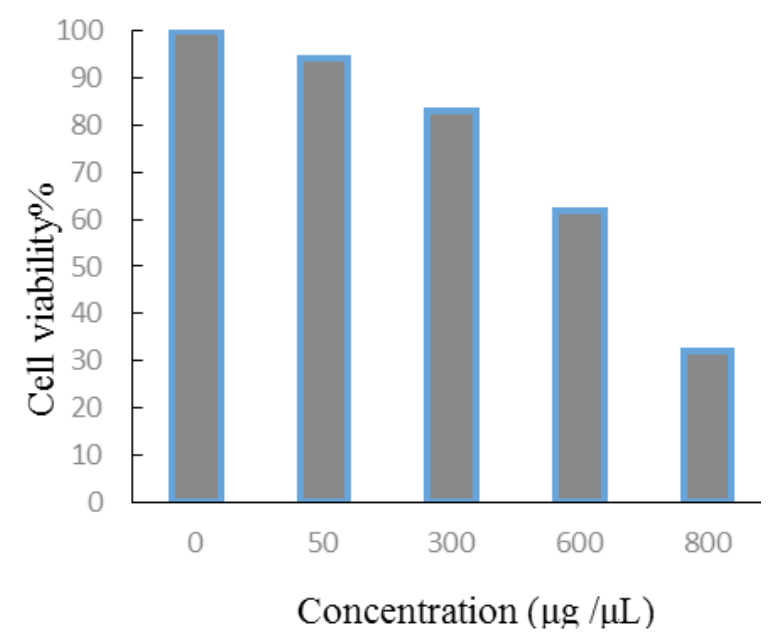

a. onn

Figure 2. The percentage of viability of breast cancer cells after treatment with different concentrations of lactoferrin 


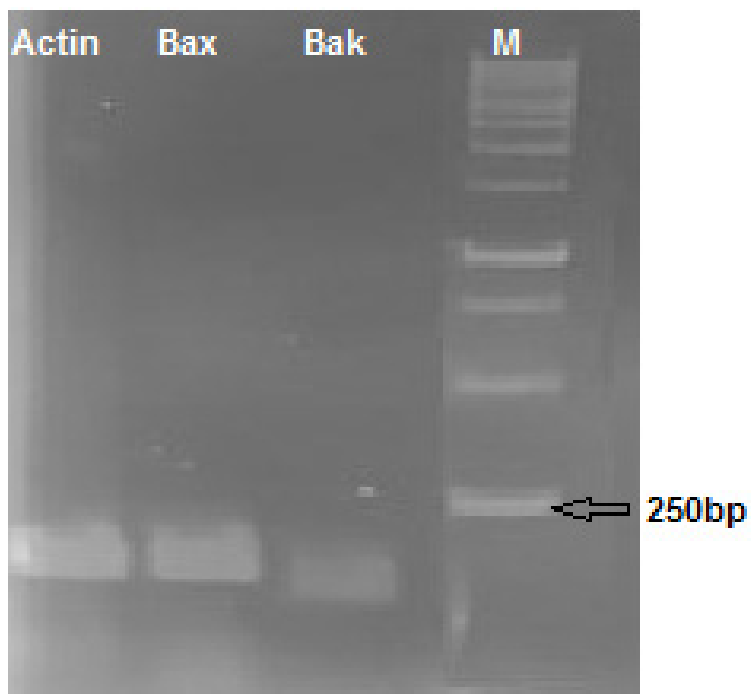

कrmm

Figure 3. Agarose gel of the amplified genes

Line 1, 151 bp band of $\beta$-actin; line 2, 150 bp band of Bax gene; Line 3, 127 bp band of Bak gene; Line 4, 1kbDNA ladder, Promega.

According to the results of this study and previous studies, the effect of lactoferrin on breast cancer cells can be described schematically (Figure 6). On the extrinsic pathway, it can increase the activity of caspase 3 and induce apoptosis. In the intrinsic pathway with the direct effect on caspase 9, as well as an indirect effect on the Bax and Bak complex, and their attachment to mitochondrial membrane and release of cytochrome $\mathrm{C}$ induce apoptosis. In this pathway, cytoplasmic cytochrome-C transiently binds the caspase adaptor molecule, Apaf1 , and consequently binds to procaspase 9 to form the apoptosome. In this complex structure, procaspase-9 dimerizes and auto-activates. Activated caspase- 9 then stimulates the caspase 3 in the extrinsic pathway, thus inducing apoptosis.

\section{Discussion}

Lactoferrin can inhibit the growth of cancer cells. In the last decade, lactoferrin has been given special attention to using as a portion of healthy natural food (milk), due to its ability to act as an anti-cancer therapeutic. In the present study, lactoferrin in a concentration of 50 to $800 \mu \mathrm{g} /$ $\mathrm{mL}$ could inhibit the growth of breast cancer cells MCF7 in a dose-dependent manner. The effects of bovine lactoferrin on human breast cancer HS578T and T47D cells showed that lactoferrin concentration from 0.125 to 125

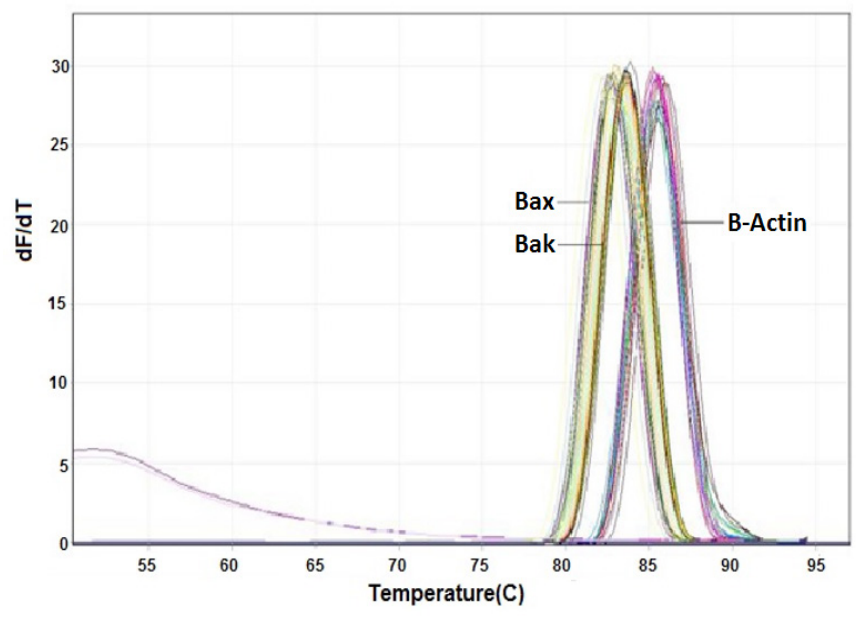

Figure 4. The graph of the proliferation of $\beta$-actin, Bax and Bak genes in a real-time PCR 


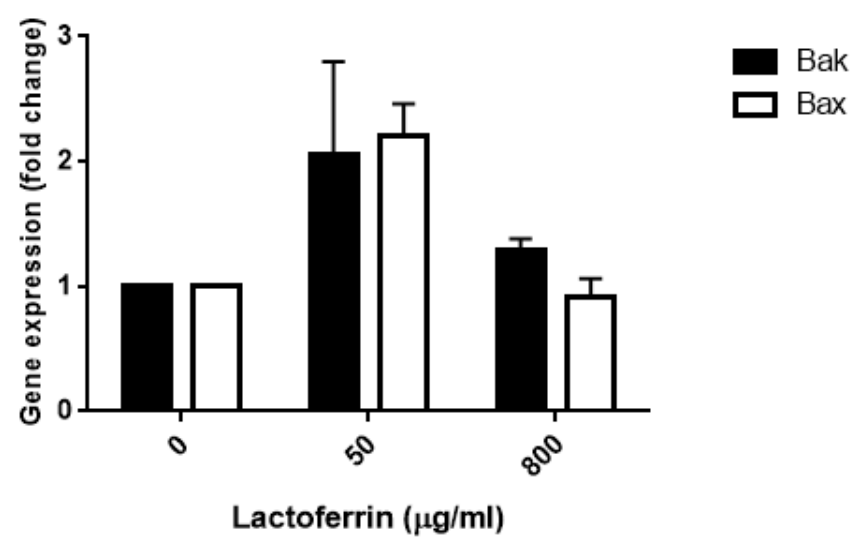

Figure 5. Comparison of the changes in the expression of Bak and Bax genes in different concentration of lactoferrin

Columns represent the fold change of Bax and Bak genes after treatment with lactoferrin relative to untreated cells. For each sample measurement were done in triplicates, error bars represent SDs $(\mathrm{P}<0.02)$.

$\mu \mathrm{M}$ decreased the cell viability of HS578T and T47D by $47 \%$ and $54 \%$, respectively [14]. Bovine lactoferrin with a concentration of $500 \mu \mathrm{g} / \mathrm{mL}$ inhibited the gastric cancer cells AGS growth by $55 \%$ and $80 \%$ during 20 and 48 hours, respectively [7]. The concentration of 500 $\mu \mathrm{g} / \mathrm{mL}$ of lactoferrin reduced cell viability in esophageal cancer cell line KYSE by $53 \%$ and $80 \%$ after 20 and 62 hours, respectively [8]. Lactoferrin B $(200 \mu \mathrm{g} / \mathrm{mL})$ was cytotoxic for different human leukemia and carcinoma cell lines [24]. Bovine lactoferrin significantly inhibited colon, esophagus, lung, and bladder carcinogenesis in rats when administered orally in the post-initiation stage [6]. The concentration of $30 \mu \mathrm{M}$ of bovine lactoferrin inhibits the growth of breast cancer cells such as MDAMB-231, HS578T, and MCF7 [29]. Both bovine lactoferrin and LferricinBs considerably reduced the viability

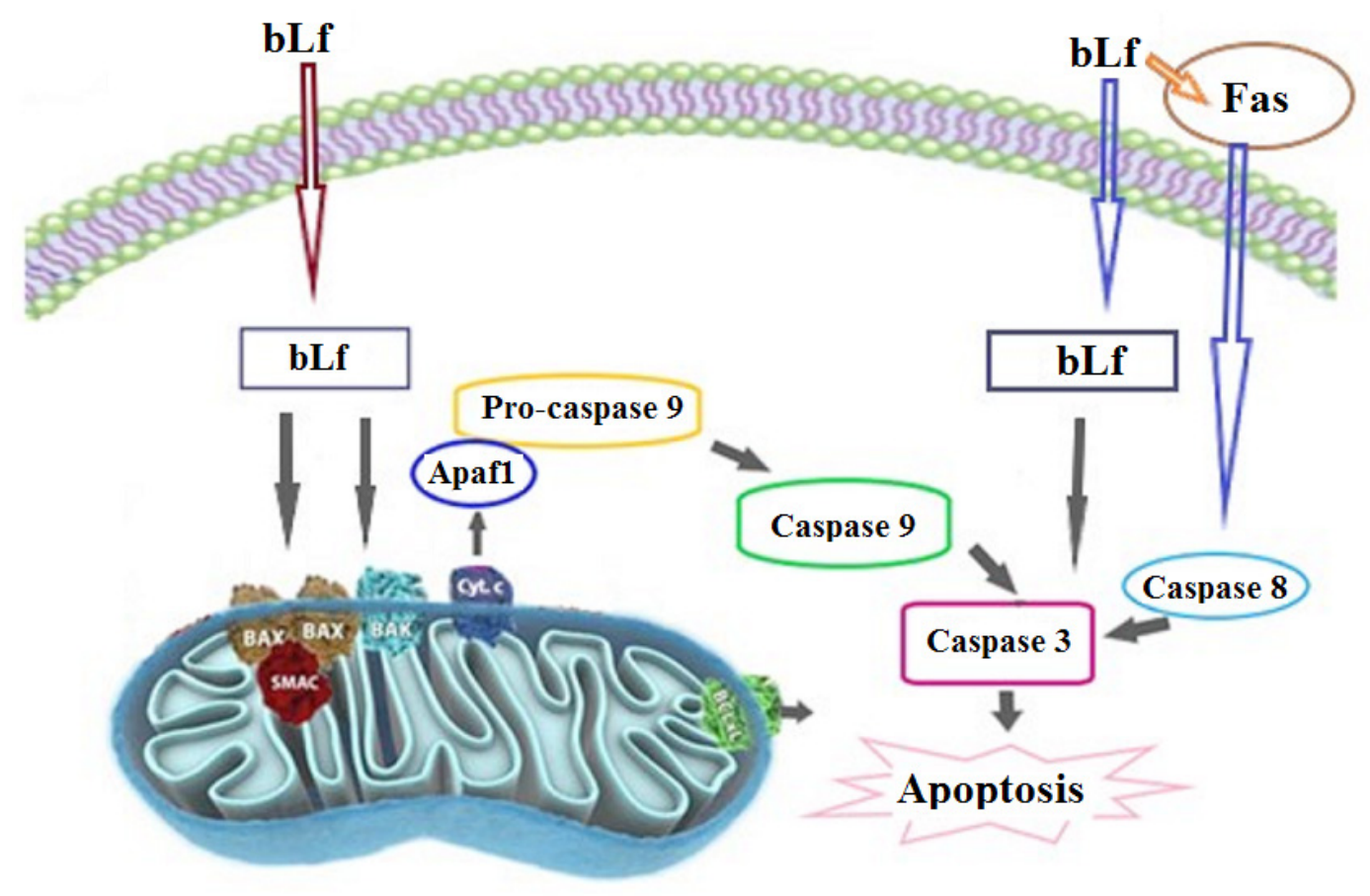

Figure 6. Lactoferrin enters the cell through its receptor and then activates the two pathways

One pathway by activating the caspases (extrinsic) and another through the mitochondrial pathway (intrinsic) 
of colon cancer cells HT-29 after $12 \mathrm{~h}$ of treatment and significantly induced apoptosis in these cells [30].

Lferricin can activate the intrinsic pathway of apoptosis by the induction of caspases 2,3 , and 9 activities in Jurkat T leukemia cells and MDA-MB-435 breast carcinoma cells [24]. Since caspases 2 and 9 act as initiating caspases for mitochondrial-dependent apoptosis, their involvement in Lfcin-induced apoptosis plays an important role in the mitochondria-dependent pathway of apoptosis and the destruction of human cancer cells [24]. Distribution of mitochondrial membrane potential is usually associated with mitochondrial membrane instability, which results in the release of cytochrome-C and other mitochondrial apoptotic proteins in the cytoplasmic compartment [24].

In this study, lactoferrin at a concentration of $50 \mu \mathrm{g} /$ $\mathrm{mL}$ could increase the expression of Bax and Bak genes. In the previous study, the expression of the Bax gene increased in mice with a tumor that fed with lactoferrin [11]. Lactoferrin inhibits the tumor growth in the colon of the azoxymethane-treated rat, which is related to the apoptosis of these cells induced by the activation of the Fas signaling pathway and enhancing Fas expression [11]. Apoptosis is a highly regulated process controlled by several signaling pathways, such as caspases and mitochondrial pathways [31].

It is known that lactoferrin induces apoptosis by the extrinsic pathway (Fas receptor family and caspases) and intrinsic pathway (mitochondria-associated). The process depends on the cell type [29]. Bax and Bak the members of Bcl-2 family are the two key molecules in the mitochondrial pathway of apoptosis. These proapoptotic Bcl-2 proteins after activation, change their conformation and oligomerize into clusters at the outer membrane of mitochondria resulting in the release of cytochrome- $\mathrm{C}$ which may indirectly activate caspase 3 from caspase 8,9 or directly by caspase 9 [21].

In the present study, the effect of lactoferrin at a concentration of $800 \mu \mathrm{g}$, showed an increase in Bax gene expression but Bak gene expression decreased in comparison to the control gene. This fact indicates that cancer cells have a very contradictory and unpredictable behavior about tumor suppressor and oncogenes genes. Also, many cancer cells inhibit the expression of tumor suppressor genes to increase their rate of growth. Furthermore, cancer cells can escape apoptosis, and therefore apoptosis promotion is one of the mechanisms to fight cancer [32]. Therefore, studying the effect of reagents on increasing the expression of genes involved in the pathway of apoptosis is important. Bax and Bak play a crucial role in the regulation of apoptosis. Heterodimerization between Bcl-2, Bax, and Bak mediated through BH3 domains is removed in many cancers [33]. Therefore, lactoferrin can induce this complex thereby facilitating the induction of apoptosis in cancerous cells. Activation of the pro-apoptotic proteins such as Bax and Bak is created through several mechanisms depending on each other and involve their translocation from the cytosol to the mitochondria membrane following the induction of apoptosis [34]. The expression of Bax and Bak genes can be influenced by other genes of the Bcl-2 family, cancer type, and different concentrations of lactoferrin. As a result, lactoferrin alone and directly cannot affect the activity and amount of these proteins. Considering the role and mechanism of lactoferrin in the pathway of apoptosis as inducing factors, we can expect the difference in the expression of genes such as Bax and Bak involved in this pathway.

\section{Conclusion}

The effect of lactoferrin on reducing the survival of cancer cells is dose-dependent and by increasing the concentration of lactoferrin, the viability of the cells decreases. According to the results, Bax and Bak genes expression increased at the concentration of $50 \mu \mathrm{g} / \mathrm{mL}$ of lactoferrin, which is likely to be more effective in expressing these genes in this type of cancer and may be considered as a defense anti-cancer mechanism.

\section{Ethical Considerations}

\section{Compliance with ethical guidelines}

This article does not contain any studies with human participants or animals performed by any of the authors. In this study, informed consent was obtained from all individual participants included.

\section{Funding}

The present paper was extracted from Fatemeh Moradian's grant at Sari Agricultural Sciences and Natural Resources University.

\section{Authors contribution's}

Conceptualization and supervision: Fatemeh Moradian and Alireza Rafiei; Matodology: Amir Khalafi; Investigation, writing and review: All authors; Writing the first draft: Amir Khalafi; Performed the review: Fatemeh Moradian; Commented on the last version; funding ac- 
quisition resources: Alireza Rafiei, Fatemeh Moradian; and all authors read and approved the final manuscript.

\section{Conflict of interest}

The authors declared no conflict of interest.

\section{Acknowledgements}

The authors gratefully acknowledge for the facility and assistance offered by the Cell and Molecular Biology Lab, Sari Agricultural Sciences and Natural Resources University.

\section{References:}

[1] Rahib L, Smith BD, Aizenberg R, Rosenzweig AB, Fleshman JM, Matrisian LM. Projecting cancer incidence and deaths to 2030: The unexpected burden of thyroid, liver, and pancreas cancers in the United States. Cancer Res. 2014; 74(11):2913-21. [DOI:10.1158/0008-5472.CAN-14-0155] [PMID]

[2] Gibbons JA, Kanwar JR, Kanwar RK. Iron-free and ironsaturated bovine lactoferrin inhibit survivin expression and differentially modulate apoptosis in breast cancer. BMC Cancer. 2015; 15(1):425. [DOI:10.1186/s12885-015-1441-4] [PMID] [PMCID]

[3] Freiburghaus C, Janicke B, Lindmark-Månsson H, Paulsson MA. Lactoferricin treatment decreases the rate of cell proliferation of a human colon cancer cell line. J Dairy Sci. 2009; 92(6):2477-84. [DOI:10.3168/jds.2008-1851] [PMID]

[4] Masuda C, Wanibuchi H, Sekine K, Yano Y, Otani S, Kishimoto $\mathrm{T}$, et al. Chemopreventive effects of bovine lactoferrin on N-butyl-N-(4-hydroxybutyl) nitrosamine-induced rat bladder carcinogenesis. Jpn J Cancer Res. 2000; 91(6):582-8. [DOI:10.1111/j.1349-7006.2000.tb00985.x] [PMID] [PMCID]

[5] Rodrigues L, Teixeira J, Schmitt F, Paulsson M, Månsson HL. Lactoferrin and cancer disease prevention. Crit Rev Food Sci Nutr. 2008; 49(3):203-17. [DOI:10.1080/10408390701856157] [PMID]

[6] Tsuda H, Sekine K, Fujita KI, Ligo M. Cancer prevention by bovine lactoferrin and underlying mechanisms: A review of experimental and clinical studies. Biochem Cell Biol. 2002; 80(1):131-6. [DOI:10.1139/o01-239] [PMID]

[7] Amiri F, Moradian F, Rafiei A. Anticancer effect of lactoferrin on gastric cancer cell line AGS. Res Mol Med. 2015; 3(2):11-6. [DOI:10.7508/rmm.2015.02.002]

[8] Farziyan MA, Moradian F, Rafiei AR. Anticancer effect of bovine lactoferrin on human esophagus cancer cell line. Res Mol Med. 2016; 4(1):18-23. https:/ / www.researchgate.net/ publication/293633992

[9] Gibbons JA, Kanwar RK, Kanwar JR. Lactoferrin and cancer in different cancer models. Front Biosci. 2011; 3:1080-8. [DOI:10.2741/s212] [PMID]
[10] Xu XX, Jiang HR, Li HB, Zhang TN, Zhou Q, Liu N. Apoptosis of stomach cancer cell SGC-7901 and regulation of akt signaling way induced by bovine lactoferrin. J Dairy Sci. 2010; 93(6):2344-50. [DOI:10.3168/jds.2009-2926] [PMID]

[11] Fujita KI, Matsuda E, Sekine K, Iigo M, Tsuda H. Lactoferrin modifies apoptosis-related gene expression in the colon of the azoxymethane-treated rat. Cancer Lett. 2004; 213(1):21-9. [DOI:10.1016/j.canlet.2004.03.029] [PMID]

[12] Yang N, Lejon T, Rekdal Ø. Antitumour activity and specificity as a function of substitutions in the lipophilic sector of helical lactoferrin-derived peptide. J Pept Sci. 2003; 9(5):30011. [DOI:10.1002/psc.457] [PMID]

[13] Zhou Y, Zeng Z, Zhang W, Xiong W, Wu M, Tan Y, et al Lactotransferrin: A candidate tumor suppressor - deficient expression in human nasopharyngeal carcinoma and inhibition of NPC cell proliferation by modulating the mitogen - activated protein kinase pathway. Int J Canc. 2008; 123(9):2065-72. [DOI:10.1002/ijc.23727] [PMID]

[14] Duarte D, Nicolau A, Teixeira J, Rodrigues LR. The effect of bovine milk lactoferrin on human breast cancer cell lines. J Dairy Sci. 2011; 94(1):66-76. [DOI:10.3168/jds.2010-3629] [PMID]

[15] Eliassen LT, Berge G, Leknessund A, Wikman M, Lindin I, Løkke C, et al. The antimicrobial peptide, lactoferricin $\mathrm{B}$, is cytotoxic to neuroblastoma cells in vitro and inhibits xenograft growth in vivo. Int J Canc. 2006; 119(3):493-500. [DOI:10.1002/ijc.21886] [PMID]

[16] Yamada Y, Sato R, Kobayashi S, Hankanga C, Inanami O, Kuwabara M, et al. The antiproliferative effect of bovine lactoferrin on canine mammary gland tumor cells. J Vet Med Sci. 2008; 70(5):443-8. [DOI:10.1292/jvms.70.443] [PMID]

[17] Adlerova L, Bartoskova A, Faldyna M. Lactoferrin: A review. Vet Med (Praha). 2008; 53(9):457-68. [DOI:10.17221/1978VETMED]

[18] Bhutia SK, Maiti TK. Targeting tumors with peptides from natural sources. Trends Biotechinology. 2008; 26(4):210-7. [DOI:10.1016/j.tibtech.2008.01.002] [PMID]

[19] Daniel PT, Schulze-Osthoff K, Belka C, Güner D. Guardians of cell death: The Bcl-2 family proteins. Essays Biochem. 2003; 39:73-88. [DOI:10.1042/bse0390073] [PMID]

[20] McCarthy NJ, Whyte MK, Gilbert CS, Evan GI. Inhibition of Ced-3/ICE-related proteases does not prevent cell death induced by oncogenes, DNA damage, or the Bcl-2 homologue bak. J Cell Biol. 1997; 136(1):215-27. [DOI:10.1083/ jcb.136.1.215] [PMID] [PMCID]

[21] Neise D, Graupner V, Gillissen B, Daniel PT, SchulzeOsthoff K, Jänicke RU, et al. Activation of the mitochondrial death pathway is commonly mediated by a preferential engagement of Bak. Oncogene. 2008; 27(10):1387-96. [DOI:10.1038/sj.onc.1210773] [PMID]

[22] Dakubo GD. The Warburg phenomenon and other metabolic alterations of cancer cells. In: Mitochondrial genetics and cancer. Berlin, Heidelberg: Springer; 2010. [DOI:10.1007/978-3-642-11416-8_2]

[23] Gross A, McDonnell JM, Korsmeyer SJ. BCL-2 family members and the mitochondria in apoptosis. Genes Dev. 1999; 13(15):1899-911. [DOI:10.1101/gad.13.15.1899] [PMID] 
[24] Mader JS, Salsman J, Conrad DM, Hoskin DW. Bovine lactoferricin selectively induces apoptosis in human leukemia and carcinoma cell lines. Mol Cancer Ther. 2005; 4(4):612-24. [DOI:10.1158/1535-7163.MCT-04-0077] [PMID]

[25] Krajewska M, Fenoglio-Preiser CM, Krajewski S, Song K, Macdonald JS, Stemmerman G, et al. Immunohistochemical analysis of Bcl-2 family proteins in adenocarcinomas of the stomach. Am J Pathol. 1996; 149(5):1449-57. [PMID] [PMM CID]

[26] Krajewska M, Moss SF, Krajewski S, Song k, Holt PR, Reed JC. Elevated expression of Bcl-X and reduced Bak in primary colorectal adenocarcinomas. Cancer Res. 1996; 56(10):2422-7. [PMID]

[27] Farrow SN, White JH, Martinou I, Raven T, Pun KT, Grinham CJ, et al. Cloning of a Bcl-2 homologue by interaction with adenovirus E1B 19K. Nature. 1995; 374(6524):731-3. [DOI:10.1038/374731a0] [PMID]

[28] Tao W, Kurschner C, Morgan JI. Modulation of cell death in yeast by the Bcl-2 family of proteins. J Biol Chem. 1997; 272(24):15547-52. [DOI:10.1074/jbc.272.24.15547] [PMID]

[29] Zhang Y, Nicolau A, Lima CF, Rodrigues LR. Bovine lactoferrin induces cell cycle arrest and inhibits mTOR signaling in breast cancer cells. Nutr Cancer. 2014; 66(8):1371-85. [DO: 10.1080/01635581.2014.956260] [PMID]

[30] Jiang R, Lönnerdal B. Bovine lactoferrin and lactoferricin exert antitumor activities on human colorectal cancer cells (HT-29) by activating various signaling pathways. Biochem Cell Biol. 2016; 95(1):99-109. [DOI:10.1139/bcb-2016-0094] [PMID]

[31] Korashy HM, Maayah ZH, Abd-Allah AR, El-Kadi AO, Alhaider AA. Camel milk triggers apoptotic signaling pathways in human hepatoma HepG2 and breast cancer MCF7 cell lines through transcriptional mechanism. J Biomed Biotechnol. 2012; 2012:593195. [DOI:10.1155/2012/593195] [PMID] [PMCID]

[32] Hanahan D, Weinberg RA. The hallmarks of cancer. Cell. 2000; 100(1):57-70. [DOI:10.1016/S0092-8674(00)81683-9]

[33] Huang Z. Bcl-2 family proteins as targets for anticancer drug design. Oncogene. 2000; 19(56):6627. [DOI:10.1038/ sj.onc.1204087] [PMID]

[34] Xin M, Li R, Xie M, Park D, Owonikoko TK, SicaGL, et al Small-molecule Bax agonists for cancer therapy. Nat Commun. 2014; 5:4935. [DOI:10.1038/ncomms5935] [PMID] [PMCID] 
This Page Intentionally Left Blank 